\title{
Serological detection of West Nile virus in horses and chicken from Pantanal, Brazil
}

\author{
Vanessa Melandri ${ }^{1 /+}$, Anthony Érico Guimarães ${ }^{1}$, Nicholas Komar², Maurício L Nogueira ${ }^{3}$, \\ Adriano Mondini ${ }^{4}$, Ana Fernandez-Sesma ${ }^{5}$, Jeronimo Alencar ${ }^{1}$, Irene Bosch $^{6}$ \\ 'Laboratório de Diptera, Instituto Oswaldo Cruz-Fiocruz, Rio de Janeiro, RJ, Brasil ${ }^{2}$ Centers for Disease Control and Prevention, \\ Fort Collins, CO, USA ${ }^{3}$ Faculdade de Medicina de São José do Rio Preto, São José do Rio Preto, SP, Brasil \\ ${ }^{4}$ Faculdade de Ciências Farmacêuticas, Universidade Estadual Paulista, Araraquara, SP, Brasil \\ ${ }^{5}$ Mount Sinai School of Medicine, New York, NY, USA ${ }^{6}$ Massachusetts Institute of Technology, Cambridge, MA, USA
}

In an effort to detect West Nile virus (WNV) in Brazil, we sampled serum from horses and chickens from the Pantanal region of the state of Mato Grosso and tested for flavivirus-reactive antibodies by blocking ELISA. The positive samples were further confirmed for serological evidence of WNV infection in three (8\%) of the 38 horses and one $(3.2 \%)$ of the 31 chickens using an $80 \%$ plaque-reduction neutralisation test (PRNT $\left.{ }_{80}\right)$. These results provide evidence of the circulation of WNV in chickens and horses in Pantanal.

Key words: WNV - b-ELISA - PRNT - Brazil

West Nile virus (WNV) genus Flavivirus; family Flaviviridae) was first detected in the Western Hemisphere during an outbreak of encephalitis in the state of New York in 1999. The virus rapidly spread through North America and later to Latin America (Komar \& Clark 2006). In South America, the first serological evidence of WNV activity was detected in horses in Colombia (Mattar et al. 2005) and later in birds in Venezuela (Bosch et al. 2007) and in Argentina (Diaz et al. 2008). In Brazil, early efforts to detect WNV activity were unsuccessful (MS/SVS 2003, 2004). The first occurrence was documented in 2010 by detection of seropositive horses in the state of Mato Grosso do Sul (Pauvolid-Corrêa et al. 2011). However, WNV has not yet been associated with human illness in Brazil (Soares et al. 2010).

The intent of the present study was to investigate the natural circulation of WNV by serological tests in domestic birds and equines in the north Pantanal Region, Mato Grosso (MT), to more completely document the area in which WNV may be transmitted within Brazil.

Study site - The study area included two farms in the Pantanal Region, between the cities of Porto Jofre and Poconé (Figure). Site A was Beira Farm (S16044'56.3" W56 51'32.6"). Site B was Campo Largo Farm (S16 39'54.3" W56 47'38.2”). Both sites are characterized by large wet pastures with patches of secondary

Financial support: Furnas Centrais Elétricas, ANEEL, INCT-Dengue/ CNPq, PRONEX-Dengue/CNPq, Panthera Foundation

VM is a recipient of the scholarship of CAPES in the Doctor of Biodiversity and Health Program at Fiocruz.

This work is part of VM's PhD Thesis at the Instituto Oswaldo Cruz-

Fiocruz-Fiocruz, Rio de Janeiro, RJ, Brazil.

+ Corresponding author: melandri@ioc.fiocruz.br

Received 24 July 2012

Accepted 6 November 2012 forest, with a rainy season from October-April and prolonged droughts in other months.

Sample collection - Blood samples were collected from the jugular vein of horses and the ulnar vein of chickens, centrifuged for separation of serum and stored at $4^{\circ} \mathrm{C}$ or $-20^{\circ} \mathrm{C}$ until being processed. All of the samples were obtained during July 2010 from clinically normal domestic animals lacking history of travel outside of the region and of vaccination against WNV.

Epitope-blocking ELISA (b-ELISA) - Chicken and horse serum samples were screened for flavivirus-reactive antibodies using b-ELISA with monoclonal antibody $6 \mathrm{~B} 6 \mathrm{C}-1$ as described previously. Any sera with inhibition $>30 \%$ was retested for specific WNV-reactive antibodies using the same protocol with WNV-specific monoclonal antibody 3.1112g (Blitvich et al. 2003).

Plaque-reduction neutralization tests (PRNT) - The ELISA-positive sera were confirmed with PRNT using WNV strain NY99-4132 and St. Louis encephalitis virus (SLEV) strain TBH-28 (Beaty et al. 1995). We required that $80 \%$ neutralization titres be at least four-fold greater for WNV than SLEV, a native cross-reactive flavivirus, to be considered indicative of WNV infection.

Of the 38 equine serum samples tested, $23(60.5 \%)$ were positive for flavivirus-reactive antibodies by $b$ ELISA. Of these, six also tested positive for WNV-specific antibodies by b-ELISA. Three of these were corroborated by the neutralization assays (Table). In addition, of 31 chickens tested for flavivirus-reactive antibodies by b-ELISA, two were positive and one was confirmed positive for WNV-reactive antibodies by both b-ELISA and PRNT (Table).

The rate of detection of WNV seroprevalence (8\%) among the horses in our study is similar to the values reported for horses in other studies within South America, such as Colombia with a prevalence of $9 \%$ (Mattar et al. 2005) and 5\% (Mattar et al. 2011), Venezuela 4\% (Bosch 


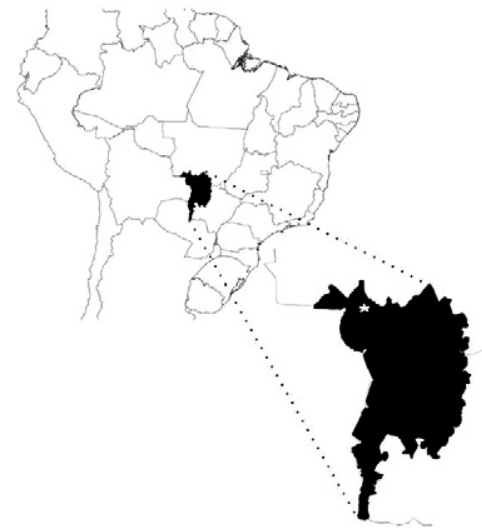

Location of sampling in the Pantanal ecological reserve, state of Mato Grosso, Brazil.

\section{TABLE}

Percentage inhibition by blocking-ELISA (b-ELISA) and 80\% neutralization titres against West Nile virus (WNV) and St. Louis encephalitis virus (SLEV) for 23 equine sera and two chicken sera that were flavivirus-reactive by b-ELISA

\begin{tabular}{|c|c|c|c|c|c|}
\hline \multirow[b]{2}{*}{$\begin{array}{l}\text { Serum } \\
\text { sample }\end{array}$} & \multicolumn{2}{|c|}{ b-ELISA } & \multicolumn{2}{|c|}{$\mathrm{PRNT}_{80}$} & \multirow[b]{2}{*}{$\begin{array}{c}\text { Flavivirus } \\
\text { type }\end{array}$} \\
\hline & $\begin{array}{c}\text { Inhibition } \\
\text { 6B6C-1 } \\
(\%)\end{array}$ & $\begin{array}{c}\text { Inhibition } \\
3.1112 \mathrm{~g} \\
(\%)\end{array}$ & WNV & SLEV & \\
\hline $\mathrm{HS}^{\mathrm{A}} 1$ & 79.3 & 33.5 & 20 & $<10$ & WNV \\
\hline $\mathrm{HS}^{\mathrm{A}} 2$ & 71.3 & 18.2 & NT & NT & UN \\
\hline $\mathrm{HS}^{\mathrm{A}} 3$ & 61.9 & 15.9 & NT & NT & UN \\
\hline $\mathrm{HS}^{\mathrm{A}} 4$ & 69.2 & 47.1 & 320 & 40 & WNV \\
\hline $\mathrm{HS}^{\mathrm{A}} 5$ & 72 & 2.3 & NT & NT & $\mathrm{UN}$ \\
\hline $\mathrm{HS}^{\mathrm{A}} 6$ & 38.1 & 17.9 & NT & NT & $\mathrm{UN}$ \\
\hline $\mathrm{HS}^{\mathrm{A}} 7$ & 69.2 & 65.7 & $<10$ & $<10$ & $\mathrm{UN}$ \\
\hline $\mathrm{HS}^{\mathrm{A}} 8$ & 57.6 & 15.5 & NT & NT & $\mathrm{UN}$ \\
\hline $\mathrm{HS}^{\mathrm{A}} 9$ & 75.2 & 18.18 & NT & NT & $\mathrm{UN}$ \\
\hline $\mathrm{HS}^{\mathrm{A}} 10$ & 35.6 & 53.4 & $<10$ & $<10$ & $\mathrm{UN}$ \\
\hline $\mathrm{HS}^{\mathrm{B}} 11$ & 67.5 & 58.7 & 40 & $<10$ & WNV \\
\hline $\mathrm{HS}^{\mathrm{B}} 12$ & 53.5 & 19.7 & NT & NT & $\mathrm{UN}$ \\
\hline $\mathrm{HS}^{\mathrm{B}} 13$ & 54.3 & 11.3 & NT & NT & $\mathrm{UN}$ \\
\hline $\mathrm{HS}^{\mathrm{B}} 14$ & 64.6 & 33.8 & NT & NT & $\mathrm{UN}$ \\
\hline $\mathrm{HS}^{\mathrm{B}} 15$ & 66.4 & 19.1 & NT & NT & $\mathrm{UN}$ \\
\hline $\mathrm{HS}^{\mathrm{B}} 16$ & 63.4 & 23.2 & NT & NT & UN \\
\hline $\mathrm{HS}^{\mathrm{B}} 17$ & 36.8 & 20.8 & NT & NT & $\mathrm{UN}$ \\
\hline $\mathrm{HS}^{\mathrm{B}} 18$ & 75.7 & 13.8 & NT & NT & $\mathrm{UN}$ \\
\hline $\mathrm{HS}^{\mathrm{B}} 19$ & 61 & 12.4 & NT & NT & $\mathrm{UN}$ \\
\hline $\mathrm{HS}^{\mathrm{B}} 20$ & 74.4 & 22.8 & NT & NT & $\mathrm{UN}$ \\
\hline $\mathrm{HS}^{\mathrm{B}} 21$ & 55 & 27.3 & NT & NT & $\mathrm{UN}$ \\
\hline $\mathrm{HS}^{\mathrm{B}} 22$ & 62.1 & 26.1 & NT & NT & $\mathrm{UN}$ \\
\hline $\mathrm{HS}^{\mathrm{B}} 23$ & 68 & 19.1 & NT & NT & UN \\
\hline $\mathrm{CS}^{\mathrm{A}} 1$ & 78.5 & 75.4 & 80 & $<10$ & WNV \\
\hline $\mathrm{CS}^{\mathrm{A}} 2$ & 54.3 & 10.5 & NT & NT & $\mathrm{UN}$ \\
\hline
\end{tabular}

$\mathrm{CS}^{\mathrm{A}}$ : chicken serum site A; HAS: horse serum site A; $\mathrm{HS}^{\mathrm{B}}$ : horse serum site B; NT: not tested; $\mathrm{PRNT}_{80}: 80 \%$ plaquereduction neutralisation test; $\mathrm{UN}$ : undetermined. et al. 2007), Brazil 3\% (Pauvolid-Corrêa et al. 2011) and Argentina 16\% (Tauro et al. 2012).

Because the chickens sampled in this study were less than one year old, we concluded that the seropositive chicken had seroconverted recently indicating active transmission of WNV, corroborating recent activity of WNV reported in the southern region of the Pantanal (Pauvolid-Corrêa et al. 2011).

We also collected some specimens of Culex nigripalpus and Culex quinquefasciatus (unpublished observations), two mosquito species that are known to be competent WNV vectors in North America (Turell et al. 2005). Potential vectors and vertebrate reservoir hosts for WNV are abundant in the vast marshes and swamps of the Pantanal ecological preserve. Limited efforts to detect WNV in local mosquitoes have been unsuccessful throughout South America.

Our data suggest that WNV is already established in Brazil. More studies are needed to assess the public health burden of WNV in Brazil, as well as the finer details of the ecology of transmission, such as the identities of vectors and vertebrate reservoirs.

\section{ACKNOWLEDGEMENTS}

To the Associação dos Cavalos Pantaneiros (Poconé, MT), for access to field sites, to Ginger Young and Nicholas Panella, for helping with laboratory testing, and to Lee Gehrke and Laura Kramer, for facilitating this research.

\section{REFERENCES}

Beaty BJ, Calisher CH, Shope RE 1995. Diagnostic procedures for viral, rickettsial and chlamydial infections. In EH Lennette, DA Lennette, ET Lennette, Arboviruses, American Public Health Association, Washington DC, p. 189-212.

Blitvich BJ, Bowen RA, Marlenee NL, Hall RA, Bunning ML, Beaty BJ 2003. Epitope-blocking enzyme-linked immunosorbent assays for detection of West Nile virus antibodies in domestic mammals. J Clin Microbiol 41: 2676-2679.

Bosch I, Herrera F, Navarro J, Lentino M, Dupuis A, Maffei J, Jones M, Fernández E, Pérez N, Pérez-Emán J, Guimarães AE, Barrera R, Valero N, Ruiz J, Velásquez G, Martinez J, Comach G, Komar N, Spielman A, Kramer L 2007. West Nile virus, Venezuela. Emerg Infect Dis 13: 651-653.

Diaz LA, Komar N, Visintin A, Júri MJD, Stein M, Allende RL, Spinsanti L, Konigheim B, Aguilar J, Laurito M, Almirón W, Contigiani M 2008. West Nile virus in birds, Argentina. Emerg Infect Dis 14: 689-691.

Komar N, Clark GG 2006. West Nile virus activity in Latin America and Caribbean. Rev Panam Salud Publica 19: 112-117.

Mattar S, Edwards E, Laguado J, González M, Alvarez J, Komar N 2005. West Nile virus antibodies in Colombian horses. Emerg Infect Dis 9: 1497-1498.

Mattar S, Komar N, Young G, Alvarez J, Gonzalez M 2011. Seroconversion for West Nile and St. Louis encephalitis viruses among sentinel horses in Colombia. Mem Inst Oswaldo Cruz 106: 976-979.

MS/SVS - Ministério da Saúde/Secretaria de Vigilância em Saúde Brasil 2003. Primeiro inquérito sorológico em aves migratórias e nativas do Parque Nacional da Lagoa do Peixe/RS para detecção do vírus do Nilo ocidental. Boletim eletrônico epidemiológico 3: 3-12.

MS/SVS - Ministério da Saúde/Secretaria de Vigilância em Saúde Brasil 2004. Inquérito sorológico em aves migratórias e residentes de Galinhos/RN para detecção do vírus da febre do Nilo ocidental e outros vírus. Boletim eletrônico epidemiológico 4: 1-12. 
Pauvolid-Corrêa A, Morales MA, Levis S, Figueiredo LTM, CoutoLima D, Campos Z, Nogueira MF, da Silva EE, Nogueira RMR, Schatzmayr HG 2011. Neutralising antibodies for West Nile virus in horses from Brazilian Pantanal. Mem Inst Oswaldo Cruz 106: 467-474.

Soares CN, Castro MJ, Peralta JM, Freitas MR, Puccioni-Sohler M 2010. Is West Nile virus a potential cause of central nervous system infection in Brazil? Arq Neuropsiquiatr 68: 761-763.
Tauro L, Marino B, Diaz LA, Lucca E, Gallozo D, Spinsanti L, Contigiani M 2012. Serological detection of St. Louis encephalitis virus and West Nile virus in equines from Santa Fe, Argentina. Mem Inst Oswaldo Cruz 107: 553-556.

Turell MJ, Dohm DJ, Sardelis MR, O'guinn ML, Andreadis TG, Blow JA 2005. An update on the potential of North American mosquitoes (Diptera: Culicidae) to transmit West Nile virus. $J$ Med Entomol 42: 57-62. 